\title{
Size-Segregated Particulate Matter and Carboxylic Acids over Urban and Rural Sites in Londrina City, Brazil
}

\author{
Adriana de M. Freitas, ${ }^{a}$ Leila D. Martins ${ }^{b}$ and Maria Cristina Solci ${ }^{*, a}$ \\ ${ }^{a}$ Departamento de Química, Universidade Estadual de Londrina, CP 6001, \\ Campus Universitário, 86051-990 Londrina-PR, Brazil
}

${ }^{b}$ Universidade Tecnológica Federal do Paraná, 86812-460 Apucarana-PR, Brazil

\begin{abstract}
Amostragens simultâneas de material particulado (PM) de 0,25 a $10 \mu \mathrm{m}$ foram realizadas entre os meses de março e abril de 2007 em área urbana e rural de Londrina (Paraná). Os resultados indicaram que o material particulado fino $\left(\mathrm{PM}_{2,5}\right)$ representa uma significativa porção da massa de material particulado $\mathrm{PM}_{10}$ (70 e $67 \%$ na área urbana e rural, respectivamente). Ácidos dicarboxílicos foram encontrados em maior concentração respondendo por $78 \%$ e $69 \%$ da massa de $\mathrm{PM}_{2,5}$ na área urbana e rural, respectivamente, sendo que o oxalato e succinato foram os mais abundantes. A distribuição de massa do oxalato em área urbana apresentou picos dominantes em 0,25-0,5 $\mu \mathrm{m}$. A razão de massa de acetato e formato indicou as emissões veiculares primarias como fonte dominante de ácidos carboxílicos em Londrina. Além disso, análises das trajetórias indicaram a ocorrência de transporte de poluentes do estado de São Paulo para a região de estudo.
\end{abstract}

Samplings of atmospheric particulate matter (PM) from 0.25 to $10 \mu \mathrm{m}$ were performed between the months of March and April 2007, simultaneously in urban and rural areas of Londrina City (Paraná State, Brazil). Results indicated that the fine fraction $\left(\mathrm{PM}_{2.5}\right)$ represents a significant portion of the $\mathrm{PM}_{10}$ mass (70 and 67\% in urban and rural areas, respectively). Dicarboxylic acids were found in larger concentration, contributing to the $\mathrm{PM}_{2.5}$ fraction with $78 \%$ in urban and $69 \%$ in rural areas, being oxalate and succinate the most abundant species. Mass size distribution of oxalate in urban site was presented as the dominant mode, with peaks at 0.25-0.5 $\mu \mathrm{m}$. Acetate-to-formate mass ratio indicated the primary vehicular emissions as dominant source of carboxylic acids in Londrina. Moreover, backward trajectories indicated the transport of pollutants from São Paulo State to Londrina region.

Keywords: size-segregated particulate matter, carboxylic acids, $\mathrm{PM}_{2.5}$, urban and rural aerosols

\section{Introduction}

The occurrence and abundance of carboxylic acids in atmospheric particulate matter (PM) depend on meteorological conditions and characteristics of the ambient. The carboxylic acids represent a major fraction of the organic acids present in the atmospheric particulate matter. Among them, the oxalic acid has been the main species, followed by succinic and malonic acids. ${ }^{1-6}$

Mono- and di-carboxylic acids are important groups of organic compounds identified in the atmospheric particles. ${ }^{78}$ Formic and acetic acids, the dominant species of organic acids in tropospheric aqueous and gaseous phases, are also ubiquitous in aerosol particles. Oxalic acid

*e-mail: solci@uel.br has been detected as the major fraction of water-soluble organic compounds in urban, rural and even in remote areas. ${ }^{3-6}$ Since carboxylic acids are highly water-soluble, they have the potential to modify the hygroscopic properties of atmospheric particles, including their ambient size and cloud condensation nuclei activity. ${ }^{9,10}$ Weak organic acids could contribute $c a .40$ and $60 \%$ to the free acidity in precipitation in urban and remote areas, respectively. ${ }^{11-13}$

Carboxylic acids have several different sources, including primary emissions from fossil fuel combustion and biomass burning, homogeneous photochemical oxidation of organic precursors from both anthropic and biogenic origin, $, 314,15$ as well as in-cloud and heterogeneous formations. ${ }^{16,17}$ Carboxylic acids in atmospheric aerosols have been investigated in several studies. ${ }^{5,8,18-26}$ The main natural emission sources are the biosynthesis of 
bacteria, mushrooms, insects (formic acid), the vegetation (responsible for 25 to $45 \%$ of the carboxylic acids (formic, acetic and pyruvic)); the pollen of plants (acetate and formate salts) and the soils. ${ }^{27}$

Dicarboxylic acids in atmospheric particulate have recently received a lot of attention for their affecting the global climate. Due to their strong hydrophilic and hygroscopic properties, dicarboxylic acids are able to reduce surface tension and affect the formation of cloud condensation, consequently affecting the global radiation balance $^{10,28-30}$ In order to characterize organic acids and their size distributions in a typical Brazilian farm plantation, as well as in an average urban city, measurements for oxalate, malonate, succinate, formate and acetate in size-segregated particulate matter were performed. Measurements for the concentration and size distributions of major inorganic ions (chloride, nitrate and sulfate) performed by Freitas and Solci ${ }^{31}$ were used to support the discussion. Particulate matter was simultaneously collected in urban and rural areas in Londrina, Brazil, between the months of March and April 2007.

Usual studies concerning atmospheric air quality as well as carboxylic acids in Brazil have been performed in large cities. ${ }^{32-38}$ For example, Vasconcellos et al. ${ }^{39}$ recently performed a comparative study of the atmospheric chemical composition of Bogotá, Buenos Aires and São Paulo Cities and found that samples from São Paulo showed the highest concentrations of species analyzed on $\mathrm{PM}_{10}$ (n-alkanes, water-soluble ions, polycyclic aromatic hydrocarbon, metals and metalloids) among all the sites. Also, Gioda et al.$^{40}$ performed studies concerning chemical composition, sources, solubility and transport of aerosol trace elements in Rio de Janeiro City. Although these large urban areas concentrate a large portion of population, investigations on urban cities with potential to become a large urban conglomeration as well as rural sites (typically used for grain cultivation) are very important since they contribute with information to understand the impacts of anthropic activities (e.g. emissions changed by land use) on the environment. In addition, atmospheric chemistry studies in South America and in Brazilian medium-sized cities, where approximately $25 \%$ of the population is concentrated, are scarce.

\section{Experimental}

\section{Characterization of sampling sites}

The Londrina City is located in Paraná State, in the south of Brazil $\left(23.30^{\circ} \mathrm{S} ; 51.15^{\circ} \mathrm{W}\right)$, occupying an area of $118.5 \mathrm{~km}^{2}$, with average altitude of $610 \mathrm{~m}$ above sea level. Its climate is sub-tropical and the summer season includes the period between December and March, while the winter season includes the period between June and September. The winter season is relatively short. Rain, which occurs throughout the entire year, is more frequent in the summer season, with annual precipitation ranging from 1500 to $1700 \mathrm{~mm}$. The metropolitan area of Londrina is composed by eleven municipalities, which occupy a total of 5,564.427 km, and hold approximately 801,756 inhabitants. Londrina has over half a million inhabitants according to the demographic census performed in $2010 .^{41}$

Two sites were chosen for the simultaneous sizesegregated PM sampling, based on typical characteristics of emission and differences in the proximity of emission sources (Figure S1 in the Supplementary Information (SI) section). The urban site is located in the heart of the city, on the ground of the Historical Museum at the intersection of three large streets in Londrina downtown. This site has intensive vehicle fleets fueled with gasohol, ethanol and diesel and it is both residential and commercial urban area. In addition, this site is close to the busiest and most important bus station in the city. Therefore, it is characterized as an urban site located at $23.31^{\circ} \mathrm{S}$ and $51.16^{\circ} \mathrm{W}$. The other site $\left(23.33^{\circ} \mathrm{S} ; 51.21^{\circ} \mathrm{W}\right)$ is located at the Experimental School Farm from the Londrina State University, which is about $5.1 \mathrm{~km}$ west of Londrina downtown. This site is a relatively unpopulated area with no significant or direct impact from vehicle emissions. However, it is exposed to emissions from agricultural activities performed on the Farm. The different characteristics of the sites made possible to investigate the contribution of sources resulting in carboxylic acid concentration in the atmosphere.

\section{Sampling methods}

Size-segregated PM samples were collected using two miniaturized cascade impactors (Sioutas ${ }^{\mathrm{TM}}$ impactors, SKC Inc.). The impactors operated at a flow rate of $9 \mathrm{~L} \mathrm{~min}^{-1}$, and consisted of four impaction stages, followed by an after-filter. Particles are separated in the aerodynamic particle diameter of quasi-ultrafine mode $(\mathrm{Dp}<0.25 \mu \mathrm{m}$; $\mathrm{PM}_{0.25}$ ), accumulation mode $(0.25-0.5 \mu \mathrm{m}, 0.5-1.0 \mu \mathrm{m}$, $\left.1.0-2.5 \mu \mathrm{m} ; \mathrm{PM}_{0.25-2.5}\right)$ and coarse $\left(2.5-10 \mu \mathrm{m} ; \mathrm{PM}_{2.5-10}\right){ }^{42,43}$ The impactors were placed $1.5 \mathrm{~m}$ above ground level and particulate matter was collected with Teflon filters (25 and $37 \mathrm{~mm}$ diameter). After being weighed, the membranes were immediately frozen and kept in a refrigerator until analysis.

Air samplings at the urban and rural sites were collected in March and April 2007 with $12 \mathrm{~h}$ intervals (daytime and nighttime). Meteorological data during each sampling 
period were obtained from the State Meteorological System (SIMEPAR). The SIMEPAR station is located at approximately $5.2 \mathrm{~km}$ far from the urban and rural sites. The weather parameters used in the development of this study were temperature, relative humidity, wind direction and speed. The average temperature, relative humidity and wind speed varied at daytime and nighttime in the ranges of 21.9-27.3 and 22.1-25.8 ${ }^{\circ} \mathrm{C}, 61.4-77.7$ and 65.8-95.3\%, 1.6-3.8 and 1.6-2.6 $\mathrm{m} \mathrm{s}^{-1}$, respectively. During this period, the predominant wind direction was East during the day and Southwest at night. Precipitation occurred only in the morning period on April 6 and during the nigh on April 24, with 6.2 and $18.2 \mathrm{~mm}$, respectively.

\section{Analysis methods}

For mass concentration measurements, the filters were weighed before and after each sampling using a microbalance with sensitivity of $1 \mu \mathrm{g}$ (AX 26, MettlerToledo Inc., Highstown, NJ) after stabilizing it under controlled moisture $(42 \pm 3 \%)$ and temperature $\left(22 \pm 2^{\circ} \mathrm{C}\right)$ for $24 \mathrm{~h}$.

The extraction method was similar to the one used by Freitas and Solci. ${ }^{31}$ Each filter was extracted from the membranes containing particulate matter using $1 \mathrm{~mL}$ of deionized water under mechanical agitation at $100 \mathrm{rpm}$ (Tecnal E140) for $90 \mathrm{~min}$ at room temperature. ${ }^{44}$ Oxalate, malonate, succinate, formate and acetate were determined by ion chromatography using a SYCAM S1100 with Dionex AG11/HPIC-AS11 separation columns and Dionex AMMS micro-membrane suppressor. Elution was carried out with a $30 \mathrm{mmol} \mathrm{L}^{-1} \mathrm{NaOH}$ solution at a flow rate of $1.5 \mathrm{~mL} \mathrm{~min}^{-1}$ and $12.5 \mathrm{mmol} \mathrm{L}^{-1} \mathrm{H}_{2} \mathrm{SO}_{4}$ solution as a

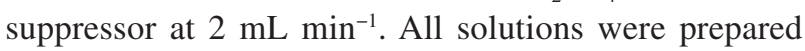
with deionized water supplied by a USF Elga system and the standards solutions by the dissolution of $99 \%$ purity analytical grade salts. The standard anion solution and the blank samples were prepared with different concentrations and given random numbers among real samples. Quality assurance procedures included the routine running of blanks and control samples as well as replicate samples. Analytical precision was better than $\pm 3 \%$. The limit of detection of the sampling method was defined as three times the standard deviation of blank unexposed impactor substrates. The average blank contamination found in field blanks corresponds to the nominal sampling volume of $6.48 \mathrm{~m}^{3}$. The results provide the limits of detection of the method (MDL) of $2.8 \mathrm{ng} \mathrm{m}^{-3}$ for acetate, $4.1 \mathrm{ng} \mathrm{m}^{-3}$ for formate, $8.3 \mathrm{ng} \mathrm{m}^{-3}$ for succinate, $2.8 \mathrm{ng} \mathrm{m}^{-3}$ for malonate and $4.3 \mathrm{ng} \mathrm{m}^{-3}$ for oxalate. Average recoveries of all species were higher than $94.6 \%$.

In the analysis of chloride, nitrate and sulfate performed by Freitas and Solci, ${ }^{31}$ the same systems and procedure used for carboxylic acids (as described above) were used. The limits of detection and quantification of the sampling method were 0.89 and $0.31 ; 0.29$ and 2.99; 1.04 and $0.97 \mu \mathrm{mol} \mathrm{L} \mathrm{L}^{-1}$ for chloride, nitrate and sulfate, respectively. ${ }^{31}$

\section{Results and Discussion}

\section{Particulate matter concentrations}

By analyzing the particulate matter concentrations found in samples from urban and rural sites, it was possible to observe that the greatest difference between the two areas lies in the fractions of fine particulate matter $(<2.5 \mu \mathrm{m})$ (Table 1). About $30 \%$ of the $\mathrm{PM}_{10}$ mass in urban site consists of coarse particles $\left(\mathrm{PM}_{2.5-10}\right)$ and the remaining $(70 \%)$ is fine particle $\left(\mathrm{PM}_{2.5}\right)$. For the rural site, the fine particle contribution was of $67 \%$. This result indicates that the fraction of fine particles represents a significant portion of $\mathrm{PM}_{10}$ mass in both sites, similar to other urban centers and areas practicing biomass burning. ${ }^{45-48}$ In addition, fine and ultrafine particles have diesel exhaust as a significant source in urban area, and these are the ones with the highest potential to cause cardio-respiratory diseases. ${ }^{49,50}$

In order to examine the behavior of the atmospheric particulate matter, mass size distributions (Figure 1) and mass concentrations of $\mathrm{PM}_{10}$ and $\mathrm{PM}_{2.5}$ were related with the set of meteorological data, which are presented in Table 2. On April 6 and 24, during the nighttime period, there was the occurrence of rain, contributing to the lowest concentrations of PM in both sites in comparison with samples collected on other days. On March 21, the direction of the wind was predominantly NW and $\mathrm{W}$, respectively, for the periods of daytime and nighttime (Table 2), different

Table 1. Average concentrations $\left(\mu \mathrm{g} \mathrm{m}^{-3}\right)$ of particulate matter in urban and rural sites

\begin{tabular}{lcccc}
\hline \multirow{2}{*}{ Particulate matter } & \multicolumn{2}{c}{ Concentration (Average $\pm \mathrm{SD}) /\left(\mu \mathrm{g} \mathrm{m}^{-3}\right)$} & \multicolumn{2}{c}{ Fraction of $\mathrm{PM}_{10}$} \\
& Urban & Rural & Urban & Rural \\
\hline $\mathrm{PM}_{2.5-10}$ & $7.34 \pm 1.73$ & $6.49 \pm 0.94$ & 0.29 & 0.33 \\
$\mathrm{PM}_{2.5}$ & $17.50 \pm 5.04$ & $13.30 \pm 4.14$ & 0.74 & 0.67 \\
$\mathrm{PM}_{10}$ & $24.84 \pm 4.78$ & $19.79 \pm 4.25$ & 1 & 1 \\
\hline
\end{tabular}


Table 2. Average concentrations of fine $\left(\mathrm{PM}_{25}\right)$ and coarse $\left(\mathrm{PM}_{25-10}\right)$ particulate matter in $\mu \mathrm{g} \mathrm{m}^{-3}$ and set of meteorological data in sampling period (daytime and nighttime) in urban and rural sites

\begin{tabular}{|c|c|c|c|c|c|c|c|c|c|}
\hline & $\begin{array}{l}\mathrm{PM}_{2.5} \\
\text { urban }\end{array}$ & $\begin{array}{l}\mathrm{PM}_{2.5} \\
\text { rural }\end{array}$ & $\begin{array}{c}\mathrm{PM}_{2.5-10} \\
\text { urban }\end{array}$ & $\begin{array}{c}\mathrm{PM}_{2.5-10} \\
\text { rural }\end{array}$ & $\begin{array}{c}\text { Precip. / } \\
\text { mm }\end{array}$ & $\begin{array}{l}\text { Wind } \\
\text { direct. }\end{array}$ & $\begin{array}{l}\text { Speed / } \\
\left(\mathrm{m} \mathrm{s}^{-1}\right)\end{array}$ & $\mathrm{RH} / \%$ & $\mathrm{~T} /{ }^{\circ} \mathrm{C}$ \\
\hline \multicolumn{10}{|l|}{ Mar/21 } \\
\hline Daytime & 23.9 & 16.8 & 10.0 & 9.26 & 0.0 & NW & 1.6 & 65.9 & 21.9 \\
\hline Nighttime & 15.4 & 21.6 & 7.96 & 12.3 & 0.0 & W & 1.9 & 74.1 & 22.3 \\
\hline \multicolumn{10}{|l|}{ Mar/29 } \\
\hline Daytime & 20.8 & 17.9 & 6.17 & 8.29 & 0.0 & E & 2.0 & 61.4 & 27.3 \\
\hline Nighttime & 14.5 & 13.3 & 5.19 & 5.23 & 0.0 & SE & 2.1 & 65.8 & 25.8 \\
\hline \multicolumn{10}{|l|}{ Apr/6 } \\
\hline Daytime & 13.8 & 18.5 & 7.72 & 6.17 & 0.0 & E & 3.8 & 73.2 & 23.7 \\
\hline Nighttime & 7.3 & 7.93 & 9.62 & 3.97 & 6.2 & SE & 1.9 & 84.3 & 22.1 \\
\hline \multicolumn{10}{|l|}{ Apr/16 } \\
\hline Daytime & 29.5 & 16.3 & 9.13 & 9.24 & 0.0 & E & 1.7 & 77.7 & 24.2 \\
\hline Nighttime & 20.5 & 15.9 & 1.41 & 4.85 & 0.0 & SE & 2.6 & 72.0 & 23.6 \\
\hline \multicolumn{10}{|l|}{ Apr/24 } \\
\hline Daytime & 19.3 & 9.43 & 3.99 & 9.68 & 0.0 & $\mathrm{~N} / \mathrm{NE}$ & 1.9 & 77.7 & 25.0 \\
\hline Nighttime & 10.3 & 2.95 & 9.15 & 2.54 & 18.2 & S/SE & 1.6 & 95.3 & 22.6 \\
\hline
\end{tabular}

from the other sampling days when the predominance of wind directions was $\mathrm{E}$ and $\mathrm{SE}$, according to information registered at the meteorological station. On this day, it can be verified that the concentrations of particulate matter represented the second highest value in both periods.

The mass size distributions of PM for urban and rural sites presented in Figure 1 showed a bi-modal distribution with similar distributions among all days sampled, except for April 6, in which the first peak at around 0.5-1.0 $\mu \mathrm{m}$, registering lower concentrations for both April 6 and 24. During these days, there was the occurrence of rain as mentioned above, and on April 6, the air mass was originated from S/SE as indicated in the backward trajectories (Figure S2). Comparing the mass size distribution between sites, there were some differences on levels (the urban level was higher) and on April 24, it shifted the peak for higher particle size. In addition, on March 29 and April 16, the second peak was not as well defined as in the other days.

In order to study the origin of air mass, backward trajectories were developed ending at 0000 UTC, with the duration of $24 \mathrm{~h}$ and with NOAA-HYSPLIT model..$^{51,52}$ The backward trajectories at the urban site for March 21, 29 and April 6, 16, 24 are presented in Figure S2. The trajectories for rural site were similar to the ones found in the urban site.

Backward trajectories of air masses arriving in the urban site were predominantly from Northeast, except for March 21 and April 6, which are in agreement with the observations made at the meteorological station. On
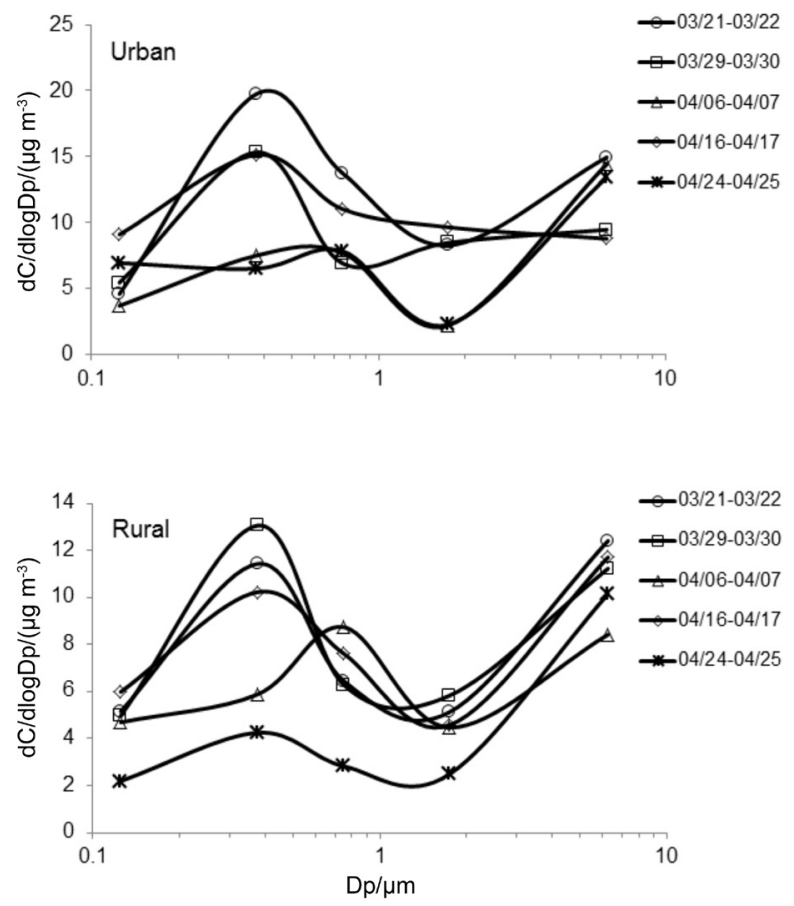

Figure 1. Mass size distributions of particulate matter in Londrina urban and rural sites (March-April, 2007)

those days, the concentrations were lower than on the days in which air masses arrived from the countryside of the São Paulo State, suggesting that Londrina region receives pollutants from São Paulo region. As already mentioned, on April 24 - nighttime, the concentration was lower because of the rain. In addition, the pollutant plumes coming from 
Table 3. Average concentration ( $\mathrm{ng} \mathrm{m}^{-3}$ ) of carboxylic acids in fractions of daytime and nighttime atmospheric particulate matter in urban and rural sites in the Londrina City (average \pm standard deviation)

\begin{tabular}{|c|c|c|c|c|c|c|c|c|c|c|}
\hline \multirow[b]{2}{*}{ Size / $\mu \mathrm{m}$} & \multicolumn{5}{|c|}{ Daytime } & \multicolumn{5}{|c|}{ Nighttime } \\
\hline & $2.5-10$ & $1.0-2.5$ & $0.5-1.0$ & $0.25-0.5$ & $<0.25$ & $2.5-10$ & $1.0-2.5$ & $0.5-1.0$ & $0.25-0.5$ & $<0.25$ \\
\hline \multicolumn{11}{|l|}{ Urban } \\
\hline Acetate & $42 \pm 18$ & $41 \pm 24$ & $26 \pm 15$ & $58 \pm 25$ & $49 \pm 17$ & $28 \pm 9$ & $17 \pm 7$ & $22 \pm 17$ & $39 \pm 22$ & $33 \pm 18$ \\
\hline Formate & $24 \pm 13$ & $26 \pm 11$ & $38 \pm 12$ & $48 \pm 15$ & $35 \pm 11$ & $44 \pm 17$ & $19 \pm 12$ & $24 \pm 9$ & $31 \pm 13$ & $19 \pm 15$ \\
\hline Malonate & $206 \pm 72$ & $68 \pm 29$ & $32 \pm 17$ & $48 \pm 21$ & $32 \pm 20$ & $180 \pm 34$ & $84 \pm 5$ & $38 \pm 10$ & $34 \pm 17$ & $22 \pm 8$ \\
\hline Succinate & $105 \pm 75$ & $244 \pm 55$ & $154 \pm 49$ & $82 \pm 22$ & $51 \pm 21$ & $80 \pm 45$ & $198 \pm 45$ & $142 \pm 31$ & $58 \pm 17$ & $24 \pm 15$ \\
\hline Oxalate & $190 \pm 18$ & $126 \pm 12$ & $145 \pm 17$ & $168 \pm 19$ & $66 \pm 11$ & $25 \pm 7$ & $108 \pm 23$ & $116 \pm 8$ & $138 \pm 44$ & $52 \pm 17$ \\
\hline \multicolumn{11}{|l|}{ Rural } \\
\hline Acetate & $47 \pm 12$ & $17 \pm 8$ & $20 \pm 17$ & $37 \pm 15$ & $49 \pm 23$ & $19 \pm 5$ & $16 \pm 9$ & $15 \pm 10$ & $36 \pm 16$ & $58 \pm 12$ \\
\hline Formate & $45 \pm 6$ & $43 \pm 3$ & $7 \pm 2$ & $11 \pm 3$ & $36 \pm 18$ & $11 \pm 8$ & $28 \pm 11$ & $11 \pm 8$ & $13 \pm 4$ & $35 \pm 11$ \\
\hline Malonate & $120 \pm 24$ & $65 \pm 13$ & $50 \pm 16$ & $38 \pm 15$ & $30 \pm 18$ & $136 \pm 12$ & $40 \pm 8$ & $20 \pm 8$ & $15 \pm 5$ & $13 \pm 5$ \\
\hline Succinate & $141 \pm 43$ & $240 \pm 11$ & $103 \pm 29$ & $45 \pm 21$ & $89 \pm 35$ & $50 \pm 18$ & $173 \pm 14$ & $39 \pm 17$ & $39 \pm 19$ & $37 \pm 13$ \\
\hline Oxalate & $17 \pm 8$ & $14 \pm 2$ & $4 \pm 1$ & $14 \pm 2$ & $2 \pm 1$ & $2 \pm 1$ & $7 \pm 2$ & $2 \pm 1$ & $4 \pm 1$ & $1 \pm 0.6$ \\
\hline
\end{tabular}

Northeast drifted over the Londrina City and travelled towards the West and Southwest of the Paraná State. The Western region of Paraná State is one of the largest producers of grains in the country.

\section{Carboxylic acids in the particulate matter}

The concentrations of mono- and dicarboxylic acids analyzed in all fraction size sampled and average concentrations in $\mathrm{PM}_{2.5}$ in the urban and rural sites are presented in Table 3 and Figure 2, respectively.

Succinate was the most abundant species, although very close to the oxalate in the urban site. Acetate and formate were found in lower concentrations when compared to dicarboxylic acids in both places. Oxalate presented higher concentration (19-fold) in the urban atmosphere (Museum) in relation to the rural site (Figure 2, Table 3). At the rural site, there was lower concentration of dicarboxylic acids when compared to the urban site.

Dicarboxylic acids in $\mathrm{PM}_{2.5}$ contributed with approximately $78 \%$ of total carboxylic acids measured in the urban site and 69\% in the rural site. Monocarboxylic acids represented 22 and $31 \%$ of the total carboxylic acids found in the urban and rural $\mathrm{PM}_{2.5}$, respectively.

In agreement with the literature, in typically urban areas, high concentrations of dicarboxylic acids were detected. ${ }^{2,14}$ On the other hand, in the particulate matter of forest and sea areas, the highest concentrations are of monocarboxylic acids. ${ }^{53}$

The average concentrations of carboxylic acids found in $\mathrm{PM}_{10}$ and $\mathrm{PM}_{25}$ in this study were compared with the concentrations found in other sites of the world (Table 4).

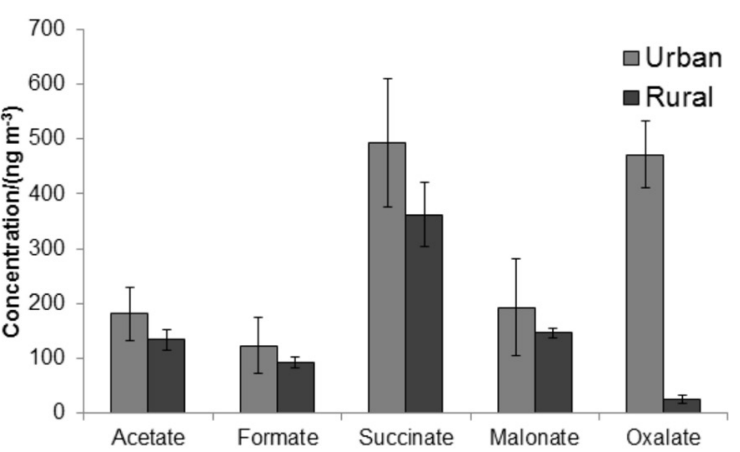

Figure 2. Average carboxylic acids concentration in $\mathrm{ng} \mathrm{m}^{-3}(\mathrm{n}=5)$ present in urban and rural $\mathrm{PM}_{25}$ in Londrina (March-April, 2007).

The concentrations of formate and acetate in Londrina were smaller than the concentrations found in São Paulo. ${ }^{19}$ However, it was similar to the concentration in Beijing for formic acid in $\mathrm{PM}_{10}$ and $\mathrm{PM}_{2.5}{ }^{24}$ Succinate and malonate presented higher concentration than in all of the compared sites. The concentration of oxalate found in this study was smaller than the ones measured in São Paulo ${ }^{19}$ and Nanjing, ${ }^{6}$ however, it was higher than in Beijing, New York and Hong Kong. ${ }^{54}$

The acids with low volatility and elevated mass molar are usually found in the particulate phase, such as dicarboxylic, oxalic, succinic and malonic acids. ${ }^{55}$ Monocarboxylic acid with low molar mass like acetic and formic acids can be present in the particulate phase, however, in low concentrations, and usually in concentrations half the size of those for acids in the gaseous phase..$^{56}$

During the study in the periods of daytime and nighttime, the average concentration for the species was analyzed. The concentrations of carboxylic acids were higher during the 
day. This fact can be attributed to the carboxylic acids formed by secondary production (photochemical reactions) and/or emitted directly by fossil fuels and processes of biomass combustion that take place more frequently during the day. As for the urban site sampling during the daytime period, the oxalate was the dominant species among those analyzed, followed by succinate and malonate.

Size distributions of mono- and dicarboxylic acids in urban and rural atmosphere are shown in Figure 3. The size distributions of carboxylic acids change from urban to rural areas, mainly for formate and oxalate. For formate, the concentration peak was in fine fraction in urban area and on coarse mode for rural. Oxalic acids in urban area were found in modes of size, although in rural areas, two modes were found.

Several atmospheric processes have been proposed to explain the observation of oxalate in the fine mode. These include in-cloud processes ${ }^{17,57}$ and gas phase photochemical reactions of hydrocarbons with oxidants followed by gasparticle condensation. ${ }^{14}$ Potential sources of oxalate can also include direct emissions from vehicle exhausts and biogenic activity, ${ }^{58}$ as well as biomass burning. ${ }^{59,60}$

Primary vehicular emission was suggested to be the main source of dicarboxylic acids in the urban atmosphere of Los Angeles. ${ }^{58}$ In fact, the secondary production of oxalic acid in the atmosphere is still not well investigated and biomass-burning and urban/industrial combustion have been known as sources of atmospheric oxalate. ${ }^{61}$

Comparing the mass size distribution of dicarboxylic acids analyzed with data obtained in other urban places, similar distribution has been found for oxalate in urban site, with the dominant mode peaking at 0.25-0.5 $\mu$ m. $^{26,62}$ According to Zhao and $\mathrm{Gao}^{26}$ if the formation pathway of oxalate in $0.32-0.56 \mu \mathrm{m}$ is dominated by in-cloud processes, the concentrations of oxalate should show a good relationship with sulfate in all samples. In this study for urban site, oxalate was highly correlated with sulfate as shown in Table 5, but in the rural site, a weak correlation was found, indicating that in-cloud processes can be considered one of those processes to explain the observation of oxalate in the fine mode. ${ }^{26}$

The patterns of succinate size distributions shifted for larger size when compared to oxalate in urban site, with peaking mode at $1.0-2.5 \mu \mathrm{m}$ suggesting photochemical formation. Malonate did not present a well defined distribution probably due to the influence of many processes, i.e., evaporation of malonate from lower diameters, photochemical formation and secondary processes. To infer about the formation pathways of succinate and malonate in urban and rural sites in Londrina, which presented different pathways from oxalate, more data are needed to further understand their formation pathways.

The use of a correlation matrix enabled the authors to suggest some sources for the carboxylic acids in the particulate phase ${ }^{19}$ The results are presented in Table 5.

In this study, the major oxalate and sulfate concentration peak occurred in the accumulation mode as already mentioned $(0.25-0.5 \mu \mathrm{m})$ in the urban and rural sites (Figure 3$)$. In the urban site, oxalate was highly correlated with sulfate $(r=0.87)$. However, in the rural site, there was a small correlation between them $(r=0.22)$. This suggests that the oxalate and urban sulfate originated from similar atmospheric processes, whereas the low correlation between sulfate and oxalic acid in the rural site indicates that the oxalic acid originated from sources and/or atmospheric processes that are different from those for sulfate.

Mass concentration ratio of malonate/succinate (M:S mass ratio) in airborne particles is useful in order to understand their importance. In this regard, a M:S mass ratio of $>3.0$ indicates that dicarboxylic acids originate from photochemical reactions associated with elevated values of oxidants and attributes the source of dicarboxylic acids to secondary reactions, ${ }^{14,63}$ whereas one of 0.3-0.5 indicates a traffic emission origin for these dicarboxylic acids. ${ }^{6,54,58}$

Table 4. Average concentration of carboxylic acids $\left(\mathrm{ng} \mathrm{m}^{-3}\right)$ measured at various sampling sites around the world in recent years

\begin{tabular}{|c|c|c|c|c|c|c|c|}
\hline Site & Size & Acetate & Formate & Succinate & Malonate & Oxalate & Ref. \\
\hline Beijing, China (urban) & $\mathrm{PM}_{10}$ & 84 & 154 & & & 377 & 24 \\
\hline Beijing, China (urban) & $\mathrm{PM}_{2.5}$ & 78 & 110 & & & 353 & 24 \\
\hline Hong Kong, China (urban) & $\mathrm{PM}_{2.5}$ & & & 70 & 30 & 350 & 54 \\
\hline São Paulo, Brazil (urban) & $\mathrm{PM}_{2.5}$ & 430 & 480 & & & 1140 & 19 \\
\hline Amazon, Brazil (forest) & $\mathrm{PM}_{10}$ & 25 & 30 & & & & 53 \\
\hline New York, USA (suburban) & $\mathrm{TSP}^{\mathrm{a}}$ & 190 & 160 & 120 & 80 & 190 & 27 \\
\hline Nanjing, China (urban) & $\mathrm{PM}_{10}$ & & & 190 & 130 & 680 & 6 \\
\hline Londrina, Brazil (urban) & $\mathrm{PM}_{2.5}$ & 180 & 120 & 490 & 190 & 470 & This work \\
\hline Londrina, Brazil (urban) & $\mathrm{PM}_{10}$ & 210 & 150 & 590 & 380 & 580 & This work \\
\hline
\end{tabular}

aTotal Suspended Particles - TSP. 
Table 5. Correlation coefficients between carboxylic acids and inorganic salts in urban and rural sites

\begin{tabular}{|c|c|c|c|c|c|c|c|}
\hline & Acetate & Formate & Succinate & Malonate & Oxalate & Chloride & Nitrate \\
\hline \multicolumn{8}{|l|}{ Urban } \\
\hline Formate & 0.06 & & & & & & \\
\hline Succinate & -0.06 & -0.24 & & & & & \\
\hline Malonate & 0.25 & -0.29 & 0.67 & & & & \\
\hline Oxalate & 0.93 & -0.14 & 0.11 & 0.42 & & & \\
\hline Chloride & -0.31 & -0.07 & 0.21 & 0.19 & -0.18 & & \\
\hline Nitrate & 0.42 & -0.06 & 0.36 & 0.88 & 0.47 & -0.11 & \\
\hline Sulfate & 0.73 & -0.32 & 0.21 & 0.26 & 0.87 & -0.13 & 0.19 \\
\hline \multicolumn{8}{|l|}{ Rural } \\
\hline Formate & -0.49 & & & & & & \\
\hline Succinate & -0.49 & 0.88 & & & & & \\
\hline Malonate & -0.41 & 0.11 & 0.51 & & & & \\
\hline Oxalate & 0.29 & -0.14 & -0.35 & -0.42 & & & \\
\hline Chloride & -0.32 & 0.71 & 0.83 & 0.58 & -0.49 & & \\
\hline Nitrate & 0.01 & 0.35 & 0.09 & -0.48 & 0.82 & -0.27 & \\
\hline Sulfate & -0.4 & 0.67 & 0.32 & -0.33 & 0.22 & 0.41 & 0.1 \\
\hline
\end{tabular}

In agreement with the high correlation of oxalate with sulfate $(r=0.87)$ and the M:S mass ratio observed in the urban site $(0.69$, much smaller than the one for secondary formation sources), ${ }^{54}$ it was suggested that the sources of oxalate and sulfate in the particulate matter stem from direct emissions of the exhaustion of vehicles. In the coarse particle mode, the concentration of oxalate was smaller than in the accumulation mode. Oxalic acid is produced in the metabolic processes of fungi and, during these processes, neither malonic acid nor succinic acid precedes oxalic acid. ${ }^{64}$ Consequently, the low correlation among the oxalate with succinate, malonate and sulfate in the rural site (Table 5) suggests that the biological source of oxalic acid is a plausible explanation to the issue in this place. This is due to the possible contribution of direct emissions of vehicle exhaustion, once it presented M:S mass ratio of 0.59 (smaller than the one found for the urban atmosphere), which can be explained by less vehicles in the rural site.

Acetate showed correlation with oxalate and sulfate in the urban site, 0.93 and 0.73 respectively, verifying the primary sources of emission, that is, direct emissions from the exhaustion of vehicles could also be responsible for the presence of this acid in particulate matter.

Similar to the study conducted in São Paulo, the formate and acetate did not show correlation, ${ }^{19}$ therefore, these ions would have been originated from different sources, that is, the formate present in the atmospheric particulate matter would not have been originated mainly from transport exhaustion like the acetate.

The main succinate concentration occurred in the fractions $0.5-1.0 \mu \mathrm{m}$, and the main concentration peak in $1.0 \mu \mathrm{m}$ in both sampling sites (Figure 3 ). Therefore, the predominance occurred in the coarse particle mode.
The same occurred with malonate, present in higher concentration in the fractions $1.0-2.5 \mu \mathrm{m}$.

Although size distributions of carboxylic acids in aerosol have been reported in some studies, ${ }^{57,65,66}$ the relationship between these and meteorological factors has not been widely discussed. Possible effects on mass concentrations and size distribution of dicarboxylic acids in particulate matter of wind direction have not been proposed. However, further research on their relationship with the productivity rates and size distribution of carboxylic acids as affected by meteorological factors needs to be conducted.

\section{Relative proportion of primary and secondary sources}

Primary emissions and photochemical transformations were suggested as the major sources of carboxylic acids. ${ }^{10}$ Studies indicate that formate is largely originated from secondary transformations. ${ }^{24}$ Previous discussions have indicated that acetate originated mainly from primary emissions, and that formate and acetate would have been originated by different sources of emission. Thus, the ratio of acetate to formate $(\mathrm{A} / \mathrm{F})$ might be an indicator of the relative importance of direct emissions (high ratio) and in situ formation by photochemical processes (low ratio). In order to verify this assumption, A/F values were collected from major primary emission sources $(\mathrm{A} / \mathrm{F}>1)$ including vehicular emission, biomass burning, and from secondary sources $(\mathrm{A} / \mathrm{F}<1)$ reported by previous studies. ${ }^{24}$ These $\mathrm{A} / \mathrm{F}$ values are listed in Table 6.

The average $\mathrm{A} / \mathrm{F}$ obtained in this study was 1.79 and 1.34 for the urban and rural sites, respectively, indicating the contribution of primary sources in both sampling places. This result indicated that the primary sources of vehicular 

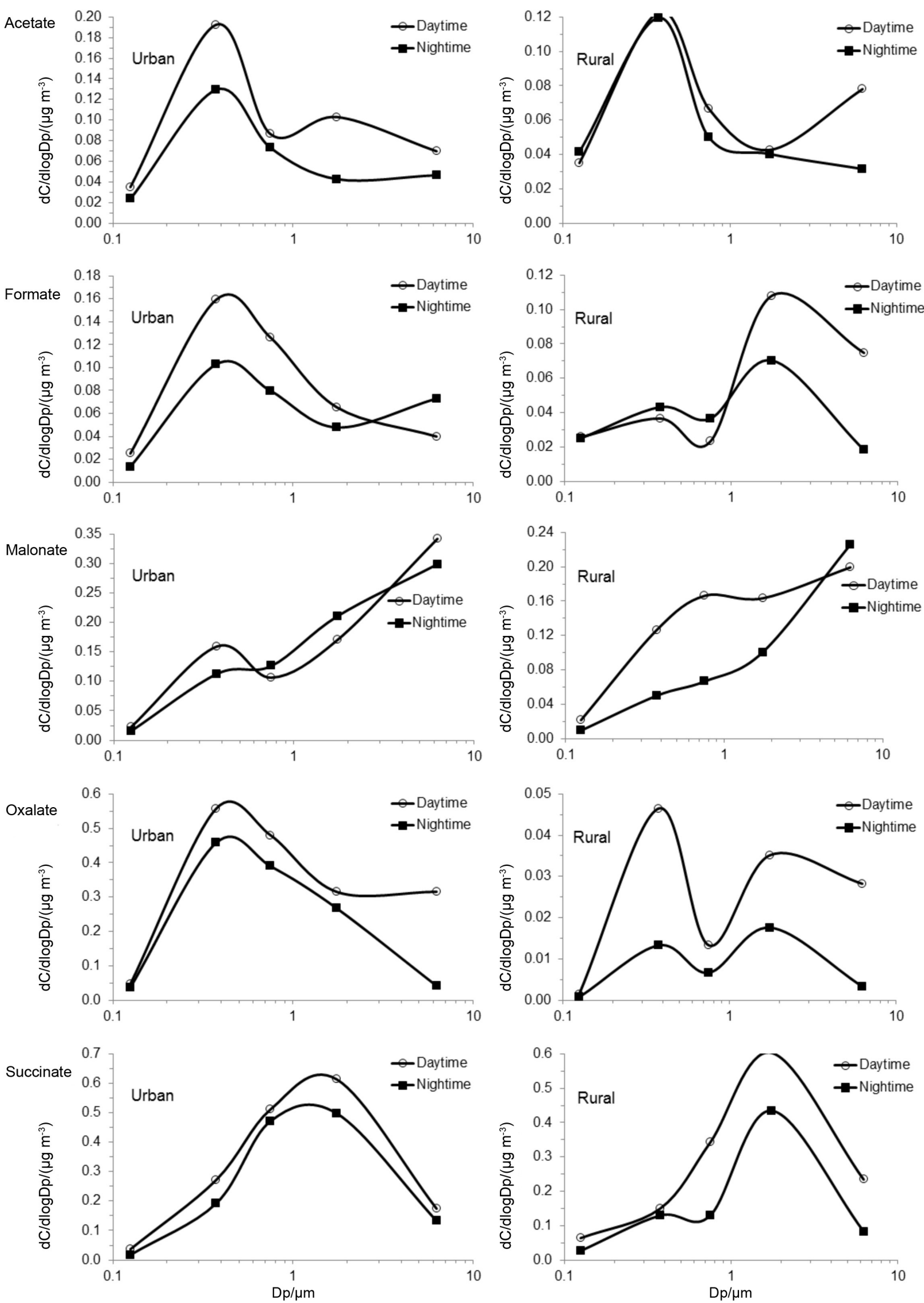

Figure 3. Average size distributions $(n=5)$ of carboxylic acids in Londrina urban and rural sites (March-April, 2007). 
emissions were the dominant source for carboxylic acids in urban and rural $\mathrm{PM}_{2.5}$ in Londrina (Table 6).

Table 6. Ratio of acetate to formate ion (A/F) from different sources

\begin{tabular}{lcc}
\hline Sources & $\mathrm{A} / \mathrm{F}$ & References \\
\hline Primary sources & $>1$ & \\
Biomass burning & $2-10$ & 67 \\
Vehicular emissions & $3-4$ & 68 \\
& $1.75-2.38$ & 67 \\
& $2.1-2.3$ & 69 \\
Secondary sources & 1.79 & this work (urban) \\
& 1.34 & this work (rural) \\
& $<1$ & 67 \\
\hline
\end{tabular}

\section{Conclusions}

The results indicated that approximately $30 \%$ of the $\mathrm{PM}_{10}$ mass in the urban site is constituted of coarse particles $\left(\mathrm{PM}_{2.5-10}\right)$ and the remaining $(70 \%)$ of fine particles $\left(\mathrm{PM}_{2.5}\right)$. Succinate was the most abundant species, although very close to oxalate in the urban site. Dicarboxylic acids contributed with approximately $78 \%$ of the total carboxylic acids measured in the urban $\mathrm{PM}_{2.5}$ and $69 \%$ in the rural sites. As a characteristic of typically urban areas, high concentrations of dicarboxylic acids were detected. Mass size distribution of oxalate was highly correlated with sulfate in urban site with the dominant mode peaking at $0.25-0.5 \mu \mathrm{m}$, but in the rural site, a weak correlation was found indicating that in-cloud processes are one of those processes that can be considered to explain the observation of oxalate in the fine mode in urban site. In addition, the low correlation between oxalate with succinate, malonate and sulfate in the rural site suggests the biological source of oxalate, as well as a possible contribution from direct emissions from vehicle exhaustion. Backward trajectories indicated transport of pollutants from São Paulo to Londrina.

To summarize, the results found from measurements performed indicate that the primary sources of vehicular emissions were the dominant sources of carboxylic acids in urban and rural $\mathrm{PM}_{2.5}$ in Londrina, but more data are needed to further understand the formation pathways of carboxylic acids in these sites.

\section{Acknowledgments}

Financial support was granted by GTZ/DAAD (Germany), CNPq, CAPES, SEMA/PR and FAEPE/UEL (Brazil).

\section{Supplementary Information}

Figures S1 and S2 are available free of charge at http://jbcs.sbq.org.br as PDF file.

\section{References}

1. Satsumabayashi, H.; Kurita, H.; Yokouchi, Y.; Ueda, H.; Atmos. Environ. 1990, 24, 1443.

2. Sempéré, R.; Kawamura, K.; Atmos. Environ. 1994, $28,449$.

3. Limbeck, A.; Puxbaum, H.; Atmos. Environ. 1999, 33, 1847.

4. Jacobson, M. C.; Hanson, H. C.; Noone, K. J.; Charlson, R. J.; Rev. Geophys. 2000, 38, 267.

5. Röhrl, A.; Lammel, G.; Environ. Sci. Technol. 2001, 35, 95.

6. Wang, G.; Niu, S.; Liu, C.; Wang, L.; Atmos. Environ. 2002, 36, 1941.

7. Rogge, W. F.; Mazurek, M. A.; Hildemann, L. M.; Cass, G. R.; Atmos. Environ. 1993, 27, 1309.

8. Limbeck, A.; Puxbaum, H.; Otter, L.; Scholes, M. C.; Atmos. Environ. 2001, 35, 1853.

9. Hara, K.; Osada, K.; Matsunaga, K.; Sakai, T.; Iwasaka, Y.; Furuya, K.; J. Geophys. Res. 2002, 107, 4399, DOI: 10.1029/2001JD001584.

10. Yu, S. C.; Atmos. Res. 2000, 53, 185.

11. Fornaro, A.; Gutz, I. G. R.; Atmos. Environ. 2003, 37, 117.

12. Galloway, J .N.; Gaudry, A.; Atmos. Environ. 1984, 18, 2649.

13. Likens, G. E.; Keene, W. C.; Miller, J. M.; Galloway, J. N.; J. Geophys. Res. 1987, 92, 13299.

14. Kawamura, K.; Ikushima, K.; Environ. Sci. Technol. 1993, 27, 2227.

15. Chebbi, A.; Carlier, P.; Atmos. Environ. 1996, 30, 4233.

16. Kerminen, V. M.; J. Aerosol Sci. 1997, 28, 121.

17. Blando, J. D.; Turpin, B. J.; Atmos. Environ. 2000, 34, 1623.

18. Krivacsy, Z.; Molnar, A.; Atmos. Res. 1998, 46, 279.

19. Souza, S. R.; Vasconcellos, P. C.; Carvalho, L. R. F.; Atmos. Environ. 1999, 33, 2563.

20. Kubátová, A.; Vermeylen, R.; Claeys, M.; Cafmeyer, J.; Maenhaut, W.; Roberts, G.; Artaxo, P.; Atmos. Environ. 2000, 34, 5037.

21. Kerminen, V. M.; Ojanen, C.; Pakkanen, T.; Hillamo, R.; Aurela, M.; Meriläinen, J.; J. Aerosol Sci. 2000, 31, 349.

22. Röhrl, A.; Lammel, G.; Chemosphere 2002, 46, 1195.

23. Limon-Sanchez, M. T.; Arriaga-Colina, J. L.; Escalona-Segura, S.; Ruíz-Suárez, L. G.; Sci. Total Environ. 2002, 287, 203.

24. Wang, Y.; Zhuang, G.; Chen, S.; An, Z.; Zheng, A.; Atmos. Res. 2007, 84, 169.

25. Hsieh, L. Y.; Kuo, S. C.; Chen, C. L.; Tsai, Y. I.; Atmos. Environ. 2007, 41, 6648.

26. Zhao, Y.; Gao, Y.; Atmos. Environ. 2008, 42, 4063.

27. Khwaja, H. A.; Atmos. Environ. 1995, 29, 127.

28. Cruz, C. N.; Pandis, S. N.; J. Geophys. Res. 1998,103, 13111. 
29. Facchini, M. C.; Mircea, M.; Fuzzi, S.; Charlson, R. J.; Nature 1999, 410, 257.

30. Kerminen, V. M.; J. Geophys. Res. 2001, 106, 17321.

31. Freitas, A. M.; Solci, M. C.; Quim. Nova 2009, 32, 1750.

32. Andrade, M. F.; Orsini, C.; Maenhaut, W.; Atmos. Environ. 1994, 28, 2307.

33. Grosjean, E.; Rasmussen, R. A.; Grosjean, D.; Atmos. Environ. 1998, 32, 3371.

34. Brickus, L. S. R.; Cardoso, J. N.; Aquino Neto, F. R.; Environ. Sci. Technol. 1998, 32, 3485.

35. Ynoue, R. Y.; Andrade, M. F.; Aerosol Sci. Technol. 2004, 38, 52.

36. Martins, L. D.; Andrade, M. F.; Ynoue, R. Y.; Albuquerque, E. L.; Tomaz, E.; Vasconcellos, P. C.; Quim. Nova 2008, 31, 2009.

37. Albuquerque, T. T. A.; Andrade, M. F.; Ynoue, R. Y.; Environ. Monit. Assess. 2011, 184, 969.

38. Vasconcellos, P. C.; Souza, D. Z.; Magalhães, D.; Da Rocha, G. O.; Water, Air, Soil Pollut., 2011, 222, 325, doi:10.1007/ s11270-011-0827-4.

39. Vasconcellos, P. C.; Souza, D. Z.; Ávila, S. G.; Araújo, M. P.; Naoto, E.; Nascimento, K. H.; Cavalcante, F. S.; Santos, M. D.; Smichowski, P.; Behrentz, E.; Atmos. Environ. 2011, doi:10.1016/j.atmosenv.2011.07.018.

40. Gioda, A.; Amaral, B. S.; Monteiro, I. L. G.; Saint'Pierre, T. D.; J. Environ. Monit. 2011, 13, 2134.

41. Instituto Brasileiro de Geografia e Estatística (IBGE), 2010, www.ibge.gov.br accessed in February, 2012.

42. Misra, C.; Singh M.; Shen, S.; Sioutas, C.; Hall, P. M.; J. Aerosol Sci. 2002, 33, 1027.

43. Minguillón, M. C.; Arhami, M.; Schauer, J. J.; Sioutas, C.; Atmos. Environ. 2008, 42, 7317.

44. Souza, S. R.; Carvalho, L. R. F.; Quim. Nova 2001, 24, 60.

45. Artaxo, P.; Martins, J. V.; Yamasoe, M. A.; Procópio, A. S., Pauliquevis, T. M.; Andreae, M. O.; Guyon, P.; Gatti, L. V.; Leal, A. M. C.; J. Geophys. Res. 2002, 107, 8081.

46. Maenhaut, W.; Jiménez, M. T. F.; Rajta, I.; Artaxo, P.; Nucl. Instrum. Methods Phys. Res., Sect. B 2002, 189, 243.

47. Artaxo, P.; Gatti, L. V.; Leal, A. M. C.; Longo, K. M.; Freitas, S. R., Lara, L. L., Pauliquevis, T. M.; Procópio, A. S.; Rizzo, L. V.; Acta Amaz. 2005, 35, 185.

48. Sánchez-Ccoyllo, O. R.; Martins, L. D.; Ynoue, R. Y.; Astolfo, R.; Miranda, R. M.; Freitas, E. D.; Borges, A. S.; Fornaro, A.; Moreira, A.; Andrade, M. F.; Environ. Monit. Assess. 2009, 149, 241.

49. Asgharian, B.; Price, O. T.; Inhal Toxicol. 2007, 19, 1045.

50. Martins, L. D.; Martins, J. A.; Freitas, E. D.; Mazzoli, C. R.; Gonçalves, F. L. T.; Ynoue, R. Y.; Hallak, R.; Albuquerque, T. T. A.; Andrade, M. F.; Air Qual Atmos. Health. 2010, 3, 29.
51. Draxler, R. R.; Rolph, G. D.; HYSPLIT (Hybrid SingleParticle Lagrangian Integrated Trajectory) Model, NOAA Air Resources Laboratory: Silver Spring, MD, 2003; http://www. arl.noaa.gov/ready/hysplit4.html accessed in November 2010.

52. Rolph, G. D.; READY Real-Time Environmental Applications and Display System, NOAA Air Resources Laboratory: Silver Spring, MD, 2003; http://www.arl.noaa.gov/ready/hysplit4.html accessed in November 2010.

53. Andreae, M. O.; Talbot, R. W.; Andreae, T. W.; Harris, R. C.; J. Geophys. Res. 1988, 93, 1616.

54. Ludwing, J.; Klemm, O.; Tellus Ser. B 1998, 40, 340.

55. Meng, Z.; Seinfeld, J. H.; Saxena, P.; Aerosol Sci. Technol. 1995, $23,561$.

56. Yao, X.; Chan, C. K.; Fang, M.; Cadle, S.; Chan, T.; Mulawa, P.; He, K.; Ye, B.; Atmos. Environ. 2002, 36, 4223.

57. Kawamura, K.; Kaplan, I. R.; Environ. Sci. Technol. 1987, 21, 105.

58. Narukawa, M.; Kawamura, K.; Takeuchi, N.; Nakajima, T.; Geophys. Res. Lett. 1999, 26, 3101.

59. Yamasoe, M. A.; Artaxo, P.; Miguel, A. H.; Allen, A. G.; Atmos. Environ. 2000, 34, 1641.

60. Lefer, B. L.; Talbot, R. W.; Harriss, R. C.; Bradshaw, J. D.; Sandholm, S. T.; Olson, J. O.; Sachse, C. J.; Shipham, M. A.; Blake, D. R.; Klemm, K. I.; Klemm, O.; Gorzelska, K.; Barrick, J.; J. Geophys. Res. 1994, 99, 1721.

61. Kawamura, K.; Sakaguchi, F.; J. Geophys. Res. 1999, 104, 350.

62. Ziemba, L. D.; Griffin, R. J.; Whitlow, S.; Talbot, R.W.; Atmos. Environ. 2011, doi:10.1016/j.atmosenv.2011.08.022.

63. Dutton, M. V.; Evans, C. S.; Can. J. Microbiol. 1996, $42,881$.

64. Yao, X.; Fang, M.; Chan, C. K.; Ho, K. F.; Lee, S. C.; Atmos. Environ. 2004, 38, 963.

65. Carvalho, A.; Pio, C.; Santos, C.; Atmos. Environ. 2003 37, 1775.

66. Müller, K.; Pinxteren, D. V.; Plewka, A.; Svrcina, B.; Kramberger, H.; Hofmann, D.; Bachmann, K.; Herrmann, H.; Atmos. Environ. 2005, 39, 4219.

67. Talbot, R. W.; Beecher, K. M.; Harris, R. C.; Cofer III, W. R.; J. Geophys. Res. 1988, 93, 1638.

68. Hartmann, W. R.; Santana, M.; Hermoso, M.; Andreae, M. O.; Sanhueza, E.; J. Atmos. Chem. 1991, 13, 63.

69. Grosjean, D.; Atmos. Environ. 1992, 26, 3279.

Submitted: March 24, 2011

Published online: April 19, 2012 